\title{
The Research of Intensive Use of Land Resources in the Process of Constructing Jinan Metropolitan
}

\author{
Xuegang Cui, Chengxin Wang \\ School of Population Resources and Environment, Shandong Normal University, Jinan, 250014, China
}

\begin{abstract}
The land is the foundation of social and economic development of the city, and the effective supply of construction land is an important guarantee for the economic development of the city. The use of land resources of Jinan metropolitan in the structure is unreasonable, and the occupation of cultivated land is serious, resulting in the low efficiency. In fact, the underlying causes of these problems are the lack of scientific planning, city boundary uncertainty, spread development and local government land finance. The methods to solve the problems include limiting city boundary, promoting the city smart growth, implementing city construction land planning strictly and cutting off the land finance of local government.
\end{abstract}

Keywords-Jinan metropolitan; land resources; intensive use

\section{INTRODUCTION}

As the material basis of human survival and place for production activities, land has an important role on human survival and development [1]. The urbanization of Jinan metropolitan is mainly rely on industrialization at the present stage. Industrialization will occupy a lot of land inevitably. Strengthen the effective management of resources and the intensive use of land resources, especially the city land resources, is a major issue of scientific concept of development.

Metropolitan economic circle has become a driving force of the rapid development of the regional economy. The rapid development of the major cities is a regular trend during the urbanization in the world [2]. As a coastal province in eastern, the economy of Shandong has an important influence in the country, and which has also formed a certain scale of the urban system. However, the development of the cities in Shandong is unbalanced between the eastern and the western, and the strength of the capital city is not strong. As an important carrier to balance the imbalance of Shandong and strengthen the radiation of the capital city, Jinan metropolitan has been given an important mission. With the rise of Jinan metropolitan, it will become an important area in the western of Shandong.

\section{THE OVERVIEW OF JINAN METROPOLITAN}

Jinan metropolitan is located in the mid-west of Shandong province, and which occupies an important position in the regional economic structure of Shandong. Jinan metropolitan includes Jinan, Zibo, Tai'an, Laiwu, Dezhou, Liaocheng and Binzhou seven cities, which has a total area of 53,000 square kilometers and population of 32.2 million. Jinan metropolitan has become a certain scale economies, but the level of economic development in cities is still unbalanced. The overall level of Jinan metropolitan is lower than the Peninsula urban agglomeration from the population, economic output and per capita economic level, but the gap is not large. Jinan metropolitan is less competitive as a whole. The strength of the core city should be enhanced, and development of the small and medium-scale city is not ideal. To form a rational urban architecture, Jinan metropolitan need to enhance the overall strength of the medium-sized cities.

\section{THE ANALYSIS OF INTENSIVE USE OF LAND IN JINAN METROPOLITAN}

A. The status quo of construction land in Jinan metropolitan

The area of the urban construction land in Jinan metropolitan is $835.3 \mathrm{~km}^{2}$ in 2007 , while the number has increased to $1055.6 \mathrm{~km}^{2}$ in 2012. The urban construction land has an increase of $26.37 \%$ within 5 years (table 1 ). With the acceleration of urbanization in Jinan metropolitan, its urban construction land area will still increase significantly.

TABLE 1 THE URBAN CONSTRUCTION LAND DATA OF EACH CITY OF JINAN METROPOLITAN IN 2007 AND 2012

\begin{tabular}{ccc}
\hline City & $2007\left(\mathrm{~km}^{2}\right)$ & $2012\left(\mathrm{~km}^{2}\right)$ \\
\hline Jinan & 315.3 & 363.2 \\
Zibo & 201.4 & 233.9 \\
Tai'an & 97.4 & 113.4 \\
Laiwu & 56.5 & 81 \\
Dezhou & 45 & 95.5 \\
Liaocheng & 57 & 64.3 \\
Binzhou & 62.7 & 104.3 \\
Total & 835.3 & 1055.6 \\
\hline
\end{tabular}

The residential land and industrial land constitute the largest two parts of urban construction land in Jinan metropolitan, which also proved Jinan metropolitan depend greatly on industrialization and industrial land in the process of urbanization (table 2). The key to achieve the intensive use of land is realizing the integration and management of industrial land more efficiently. 
TABLE 2 THE DISTRIBUTION TABLE OF VARIOUS TYPES OF CONSTRUCTION

\begin{tabular}{ccccc}
\multicolumn{5}{c}{ LAND IN JINAN METROPOLITAN IN $2012\left(\mathrm{KM}^{2}\right)$} \\
\hline City & $\begin{array}{c}\text { Residential } \\
\text { land }\end{array}$ & $\begin{array}{c}\text { Public } \\
\text { facilities }\end{array}$ & $\begin{array}{c}\text { Industrial } \\
\text { land }\end{array}$ & $\begin{array}{c}\text { Transportation } \\
\text { facilities }\end{array}$ \\
\hline Jinan & 92.4 & 13.4 & 69.3 & 66.8 \\
Zibo & 79.4 & 5.5 & 67.1 & 25.3 \\
Tai'an & 43.6 & 1 & 21 & 19 \\
Laiwu & 21 & 4.7 & 16.7 & 3 \\
Dezhou & 26.3 & 2.5 & 26.3 & 12.9 \\
Liaocheng & 17 & 0.6 & 18.2 & 9.3 \\
Binzhou & 31 & 2.6 & 22.2 & 15.5 \\
Total & 310.7 & 30.3 & 240.8 & 151.8 \\
\hline
\end{tabular}

B. The problems and causes of intensive use of construction land in Jinan metropolitan.

The urban sprawl and the concept of development is unscientific. The stage of economic development of Jinan metropolitan determines the urban construction land is still in the "extension and expansion" model of development, and lack of connotative building ideas in urban construction. The construction costs of epitaxial development is low and the effect is significant, while the costs of connotative development is high (such as urban renewal and demolition). However, according to supply and demand of construction land in Jinan metropolitan, this theory of urban development is not scientific [3].

The master planning of land use and urban planning does not match. At present, the urban planning of Jinan metropolitan is ahead of land use planning in terms of time, which has formed preconceived situation. When determining the scale of the land, land use planning is often followed by the urban planning. However, the urban planning emphasizes the internal construction of urban, and most of the them only analyze the urban land demand, lacking the feasibility analysis of urban land supply. This causes the intensive use of land in the two departments can not convergence in the late and lacking of unified supervision of land use. Then it is difficult to ensure the intensive use of construction land [4].

The land reuse is hard in some enterprises Jinan metropolitan has a large number of idle and inefficient land, a part of which belongs to the enterprises in the period of planned economy. As the existing institutional reasons, it is difficulty to do the land reuse.

\section{THE MEASURES OF INTENSIVE USE OF LAND IN JiNAN METROPOLITAN}

A. Improve and implement the planning policies, strengthen the pre-trial of land use and establish restraint mechanisms economical and intensive use of land.

The pre-trial of new construction land should be considered several factors. Firstly, check the stock of construction land that can be used. If the stock of construction land is suitable, it couldn't be increased.
Secondly, when doing the pre-trial of land use, the inefficient land which can be replaced in the area should be known. If there is the inefficient land which can be replaced, using it could be given the preferential policy.

\section{$B$. Define the urban growth area.}

Urban growth area refers to the area that can accommodate urban growth in the overall urban planning, which is delimited by the boundary of urban growth and service. All the growth is limited within the boundary, and only agriculture, forestry and other non-urban land use could be developed out of the boundary. Define the urban growth area is a way to control the total amount of construction land. In the urban planning, determine the total amount of construction land in demand according to urban land demand and the minimum land use intensity in the planning period, and do the spatial orientation on the land demand based on the existing construction land, then the urban growth area will be defined [5].

\section{Implement filled development and redevelopment.}

Filled development and redevelopment are basic technical measures to improve the intensity of land use which are advocated by urban smart growth management. Filled development refers to make full use of the idle land which is fully furnished with public facilities in the urban area. Redevelopment refers to replace and reuse the existing structure of land use, which is the further strengthening developments of the developed land, and the purpose is to change the low-density pattern of land use which is caused by urban sprawl development. Not only for construction land, redevelopment land can also be used to improve the quality of life, such as being used as green space and open space.

\section{ACKNOWLEDGEMENTS}

This study was Supported by financing projects of the National Natural Science Foundation (approve No.41371170), and technology project of Shandong Province (2012GSF12204).

\section{REFERENCES}

[1] P.P. Xie. Research on evaluation of urban construction land intensive use of six cities which in Shandong peninsula blue economic zone. Central China Normal University, 2011.

[2] X.G. Peng. The research of intensive use of land resources in the process of constructing Chazhutan urban agglomeration. Journal of Hunan Institute of Administration, 2013.

[3] S.J. Hong. Study on China's metropolitan governance transformation based on new regionalism. Urban Planning International, 2010.

[4] S.P. Cai. Evaluation of exploitable land resource in core area of Changsha-Zhuzhou-Xiangtan urban group. Journal of Hunan University of Commerce, 2013.

[5] Q. Yin, C.F. Wu. Rational growth_-a new concept of urban growth in America. Journal of China University of Mining and Technology, 2005. 